Women's Studies

An interdisciplinary journal

ISSN: 0049-7878 (Print) 1547-7045 (Online) Journal homepage: https://www.tandfonline.com/loi/gwst20

\title{
Structural Violence and Scientific Activism in Mexico: A Feminist Agenda
}

\section{Gabriela Méndez Cota}

To cite this article: Gabriela Méndez Cota (2019) Structural Violence and Scientific Activism in Mexico: A Feminist Agenda, Women's Studies, 48:3, 186-206, DOI: 10.1080/00497878.2019.1593843

To link to this article: https://doi.org/10.1080/00497878.2019.1593843

册Published online: 29 Apr 2019.

6 Submit your article to this journal

Џ Article views: 37

View Crossmark data \lceil 


\title{
Structural Violence and Scientific Activism in Mexico: A Feminist Agenda
}

\author{
Gabriela Méndez Cota \\ Universidad Iberoamericana, Ciudad de México
}

\section{Introduction}

In 2009, Sandra Harding observed that the boundaries of feminist science studies (FSS) were mostly established in the North at the expense of intercultural dialog with the South, and that much of the feminist conversation around science has often been conducted separately from postcolonial interrogations of Eurocentrism. More recently, Angela Wiley argued that contemporary theoretical trends in FSS, such as "new materialisms," are at risk of reasserting Eurocentric and disciplinary ways of knowing as well as "the historic whiteness of feminism" by largely ignoring the epistemological insights that foreground power and accountability in knowledge construction and that were foundational to the Northern feminist critique of science (Rose). While postcolonial feminism and decolonial discourses are currently performing much needed interventions in FSS as well as in related fields such as science and technology studies (STS) (Lyons et al.; Pollock and Subramanian), the purpose of this article goes beyond expanding the scope of established academic fields such as FSS and STS, and stops short of "decolonizing" FSS if such a gesture would demand a radical break from the whole of feminism's intellectual history. Moreover, and taking heed of Tania Pérez Bustos's caution against any homogenizing appropriation of decolonial thinking from Latin America, I set out instead to prepare the ground for a situated-hence necessarily partial-critique of "science" narratives in Mexico. My overall argument is that such a critique has the potential to contribute not just to the academic questioning of knowledge production in Mexico but also to pushing the boundaries of what feminist critique can do in a context wherein feminism and science studies appear to be unrelated. If FSS is to have a future in Mexico as an academic practice of "situated knowledges" in Donna Haraway's sense, the first task is to articulate feminism with science studies, and to do so attending to the specific histories of each in the Mexican context.

In the first section I provide a historical overview of structural violence, science studies, and feminism in Mexico. Structural violence appears first as 
the immediate context in which some Mexican scientists and academics have recently intensified their struggles to articulate "science" with social justice. Yet I offer a deeper account of how several decades of structural violence have shaped the agendas of both science studies and feminism in the Latin American region, including their failure to converge as an interdisciplinary formation such as FSS. Against this backdrop, questions emerge as to how feminism, as a site for the generation of situated knowledges, can today relate to science studies in a Mexico. As a way of bridging the gap, widened by structural violence, between academic "science studies" and the political work of feminism, in the second section I look at the recent institutionalization of a "gender and science" discourse in Mexican science policy as an instance of so-called neoliberal feminism, and I contrast its cultural and political effects with the project of a socially concerned "science." As a more promising starting point for a situated practice of FSS, in the third section I turn my attention to recent collaborations between STS scholars concerned about forced disappearances, people searching for missing relatives, and forensic anthropologists. In addition to providing counterpoints to the "women and science" narrative, the ethical issues emerging from these collaborations help me to identify the feminist core of a future agenda for science studies in Mexico. Through my reading of a debate resulting from one such collaboration, I articulate a kind of feminist critique that I think is relevant in Mexican scientific and technological debates today.

\section{Structural violence, science studies, and feminism in Latin America}

Structural violence has been defined somewhat narrowly by Runyan and Peterson as the choice, typical in neoliberal states, to privilege military spending at the expense of making populations more vulnerable to social, economic, health, and environmental harms. In Mexico, structural violence has been most evident since 2006, when then President Felipe Calderón declared a "war on drugs" that resulted, over the last 12 years, in tens of thousands of unexplained murders and unresolved disappearances throughout the Mexican polity. Yet a deeper cause of structural violence, namely neoliberal globalization, announced itself in Mexico as early as the 1980s, when the country was hit by economic crisis and structural adjustment policies began to replace the importsubstitution regime of post-revolutionary Mexico (Schmidt). Ever since, Mexico's population has been systematically subjected to social, economic, health, and environmental harms, while the "war on drugs" of recent years underscores a decision to obscure the structural causes of such harms through simplified narratives of police and thieves. According the Final Ruling (2014) of the Permanent Peoples' Tribunal (PPT), when the North American Free Trade Agreement (NAFTA) came into effect in 1994, Mexico became the site of the first experiment in the world with unconditional guarantees for capital 
investment. ${ }^{1}$ NAFTA replaced the Mexican manufacturing sector with reindustrialization processes in which assembly operations (maquiladoras) were made to serve a transnational economy. Likewise, an environmentally destructive, export-oriented agriculture replaced the country's strategic reliance on protected food prices and subsistence-oriented agriculture. A series of constitutional reforms legalized these aggressive processes, starting with the 1991 reform of Article 27, which used to protect collective ownership of land since the Mexican Revolution (1910-1921). As Mexico was steadily colonized by transnational firms throughout the 1990s, the country headed into a political turmoil, which was only faintly appeased by the neoliberal rhetoric of a "democratic transition." Between 2000-the year that marked the end of one-party rule-and 2014, decentralization policies channeled more money to Mexican states than Europe received from the Marshall Plan, but since no corruption control mechanisms were in place Mexico thus saw the emergence of a plutocratic governing class with little interest in a political mitigation of neoliberalism. The latest reforms to the Constitution, from 2014, expanded rights to oil extraction by Mexican companies to gas, shale gas, wind, and solar energy extraction by US oil and gas companies, Spanish electricity companies, and Canadian mining companies, all of them supplying the US market. In the words of Mexican environmental lawyer and PPT witness Raymundo Espinoza, the neoliberal state managers "bothered to legalize the violations of the rights of the people; they have recognized and guaranteed the privileges and private interests of a few against the public interest, going as far as ignoring the minimal conditions for the reproduction of social life" (210). Structural violence has forced millions of Mexicans to migration. Those left behind, women and children as well as men, became increasingly vulnerable to the most extreme forms of violence- which is supposedly "drug-related" but in fact appears diffuse and difficult to explain in comparison with earlier dynamics of politically motivated "dirty war." Such is the context of structural violence in which the question concerning feminist science studies must be raised for the latter to have a future in Mexico as a practice of situated knowledges.

The role of globalized Western science and technology in the perpetuation of structural violence recently started coming into focus in the Mexican public sphere via concerns more recognizable to Mexican majorities such as human rights, social justice, and environmental depletion. Between 2006 and 2014, a nationwide network of environmental struggles was integrated into the National Assembly of the Environmentally Affected (ANAA), which describes itself in its website as a popular, pacific, and organized response to

\footnotetext{
${ }^{1}$ The PPT is an independent tribunal based in Rome that investigates crimes against humanity. A descendant of the 1967 Bertrand Russell-Jean Paul Sartre Vietnam War Crimes Tribunal, the PPT applies international law and policy to cases brought before it. In each case, thousands of documents and witness statements are reviewed throughout a series of hearings, resulting in a Final Ruling. My brief description in this paragraph of structural violence in Mexico is based on the Final Ruling corresponding to the Mexican Chapter of the PPT. See Permanent Peoples' Tribunal.
} 
environmental devastation in Mexico and the world, an embodiment of the Mexican people's increasing awareness of the wider scale of their local plights, and as a space for the encounter of neighborhoods, towns, communities, and organizations (Asamblea Nacional de Afectados Ambientales). ANAA founder Andrés Barreda Marín is a professor of political economy at Mexico's National Autonomous University (UNAM) who in 2007 also founded, together with high-profile molecular biologist Elena Álvarez Buylla, the first Union of Concerned Scientists (UCCS) in Latin America. The two organizations have collaborated closely on a variety of issues, starting with the release of transgenic corn in the Mexican countryside, which they regard as a neoliberal weapon against Mexican sovereignty. While the ecological defense of native maize and peasant agriculture has become the UCCS's signature issue, ANAA has developed into a network of hundreds of local struggles against environmental violence. At one point, in 2009, the Assembly agreed that there was a direct connection between neoliberal "free trade" and the multiple experiences of environmental violence that ANAA members had experienced and shared with each other. Eventually, ANAA became the main petitioner and coordinator of the Mexican chapter of the Permanent Peoples' Tribunal. In 2014, the PPT ruled that the Mexican government was guilty of structural violence, that is, of committing "abuse of power" against the Mexican population in collusion with transnational capital, the policies of the United States of America, and criminal organizations. While "violence against women" was one of the six "thematic sections" of the Mexican Chapter of the PPT, neither UCCS nor ANAA have yet released or attracted explicitly feminist analyses of science and technology as the latter are understood and challenged by socially concerned scientists in their struggle against structural violence. This article seeks to start working in that direction by interrogating, in the first place, the relationship between science studies and feminism in the Latin American region. As is well known, in parallel to the historiographic revolution associated with the work of Thomas Kuhn, feminist and postcolonial STS have done much to challenge the conventional account of "science" as a "critical attitude toward conventional beliefs, a distinctive method, uniquely high standards of objectivity, a distinctive rationality, a distinctive metaphysics ..., a mechanistic model of nature, and the reliance on mathematics" (Harding, Is Science Multicultural? 56). Since I am interested in contemporary challenges to what Harding calls "a relic of western folk belief" (14) and that which, as she observes, continues to permeate popular and institutional discourses on "science," I begin my historical contextualization with the cultural and political revolution that the sixties represent in Mexico as in the rest of the world, and that provided a long-lasting yet differential inspiration to activist initiatives such as ANAA and UCCS, on the one hand, and feminisms on the other hand.

In the sixties, the Mexican student movement forcefully articulated a social desire for cultural and political democratization that was met with violent 
repression on the part of the state. As recounted by Joseph, Rubinstein, and Zolov, after the Tlatelolco massacre of October 2, 1968, the Mexican government's strategy combined counterinsurgency tactics against political dissidents with a neo-nationalist interpellation addressed to the urban middle classes. In tune with international agendas and prescriptions (Finnemore), the government promoted "science" and "technology" as universally valid instruments for the sovereign "development" of Mexico, and for such a nationalist purpose it created science policy and educational bureaucracies such as the National Council for Science and Technology (1970). By the 1990s, following a decade of economic crisis and structural adjustment measures, "science and technology" were reframed through the neoliberal narrative of modernization as free trade, or as entry into global commercial competition (see OToole). The government now promoted treaties such as NAFTA as a promise to enter the so-called First World, and thus national sovereignty came to rely on the adoption of technoscientific values such as business, innovation, and "impact." Although academic legatees of the sixties promptly denounced the link between such a technoscientific shift in the national science policy and the government's traditional authoritarianism (Schoijet and Worthington), neoliberalism prevailed and to this day shapes the criteria of the national science bureaucracy, which allocates resources for the training of new scientists and technologists in Mexico and abroad, selects national research projects for state funding, evaluates and rewards the performance of individual researchers, and it even channels shares of the science budget toward national and transnational industries claiming to invest in technological innovation. As in much of the Western world, neoliberalism eventually ceased to be perceived, at least in academic contexts, as an authoritarian imposition, in order to become common sense or, as in Wendy Brown's Foucauldian terminology, a political rationality that produces, rather than represses, Mexican knowledge producers. At present, however, both science studies and feminism, however, constitute potential sites of reflection and rectification of such a trajectory in Mexico and in much of Latin America. The Latin American experience of structural violence, I now turn to suggest, has kept separate the regional agendas of science studies and feminism, and has now the potential to articulate them through a situated practice of FSS.

To make the point, let me offer a brief generational overview of Latin American STS, based on recent accounts by longstanding scholars of the field (Kreimer et al.). The first generation of Latin American STS is associated with left-wing men of science, such as Argentinian Óscar Varsavsky, who sought, between the fifties and the eighties, to institutionalize a progressive link between science and society by means of militant essays. Writing from the nationalist standpoints that were typical of dependency theory during the Cold War, some of those early thinkers echoed the radical science movement 
that emerged from the global protests of the sixties, and that contested the ideological neutrality of science as well as its imperialist uses and applications (Rose and Rose). With the global decline of political militancy from the eighties onward, a second generation of Latin American STS devoted itself to the constitution of an academic field by means of training programs, research areas, and publications. A constructivist approach became dominant that was informed not just by the historiography of Thomas Kuhn but also by the sociology of Pierre Bourdieu. As STS became increasingly professionalized, its practitioners abandoned the traditional genre of militant essays decrying scientific and technological dependence, adopting instead the genre of research papers around case studies. Such a replacement of militant essays by empirical case studies entailed, according to contemporary scholars (Casas Guerrero), a loss of critical reflection on the role of science in society, for case studies tended to be assembled in accordance with the criteria and concepts of neoliberal science policies, such as technical innovation and market value. Significantly, "gender" (rather than feminism) made its first appearances in relation to "science" as part of this neoliberal tendency, and before I look at how "gender" appeared specifically in Mexico, I turn to diagnosing the position of feminist theory and critique within Latin American STS.

To put it bluntly, an equivalent to FSS does not stand out as a distinctive academic conversation either within or without STS in Latin America. While some work in the field does explore issues and develops approaches that could find resonances with FSS (Medina, da Costa Marques, and Holmes; Smith and García Deister), feminist theory and critique as such seem close to absent from the STS field, with the meager literature on gender focusing on liberal issues of representation and inclusion such as the number of female academics that contribute to either the mainstream sciences or the field of STS itself (Blázquez Graf and Flores; Flores Espíndola; Lopes et al.). My own quick survey merely seems to confirm Sandra Harding's more general diagnosis that Northern research trajectories on gender and science, which rapidly expanded from accounting for the presence of women in the sciences to feminist critiques of and alternatives to androcentric epistemologies, ontologies, and methodologies, have been rather "slow to gather steam among researchers and activists from other parts of the world" (404). Under the light of recent speculative and practical engagements with technoscience such as "new materialisms" (Alaimo and Hekman; Cipolla et al.), the marginality and the narrowness of gender issues in Latin American STS becomes even more apparent. While one may resort to the explanation that historically Latin American STS has been animated by (arguably androcentric) revolutionary and disciplinary discourses that have tended to separate scientific issues from women's concerns, it might be just as important to contextualize the priorities, strategies, and tensions of Latin American feminisms as something that may continue to bear, even if indirectly, on the 
constitution of FSS as an academic field. It might turn out that the first task of a situated FSS is to culturally and politically articulate that which has come to appear as disconnected as a matter of fact and to do so by making the connection between feminism, science, and structural violence.

In her assessment of Nancy Fraser's Marxist critique of second-wave feminism, Verónica Schild observes that in Latin America “... the capitalized state of the seventies was not the depoliticized bureaucracy that Fraser describes but more often a brutal military dictatorship, heavily gendered, aiming at the physical eradication of left opposition and defending starkly unequal property relations" (61). In other words, extreme manifestations of structural violence gave specific challenges to Latin American feminisms, which were never exclusively in the hands of the paradigmatic subject of the second wave, namely, "a new generation of highly educated women, who were not content with being the helpmates of male revolutionaries" (63). According to Schild, Latin American feminisms were configured through a specific kind of "interclass solidarity" against dictatorships in which structural inequalities among women were negotiated although often reproduced through "a pedagogic relation in which educated activists aimed to help 'other' women to gain their own autonomy" (65). Thus, the common focus of Latin American feminisms was not, as in Fraser's account, the gendered division of labor at work and at home, but rather a radical notion of "autonomy" that continues to be disputed by very unequally positioned women. In the seventies and eighties, the possibility of "creating one's own space, not just physically but also emotionally and psychologically, by breaking with traditional femininity" (65), appeared as the project of well-educated, middle-class feminists, and often ran counter to the maternalist positions of religious groups influential in the region. Hence the historical challenge of Latin American feminisms, which has been to articulate modern visions of women's autonomy with the material and symbolic struggles of the majorities; that is, of working-class or rural and indigenous women under conditions of structural violence. Not surprisingly, the institutionalization of such feminisms since the 1990s has revolved around political issues-violence against women, reproductive justice, and free sexual choice-that have come to appear as disconnected from STS. Nevertheless, certain common features in the parallel trajectories of Latin American STS and Latin American feminisms may be taken as starting point for a future articulation of FSS.

Partly under the influence of feminist activism on global policy arenas, by the late 1980s "gender" had gradually come to replace "women" in national policies and research programs, deepening already existing divisions between "institutionalized" and "autonomous" feminists (Alvarez and DaCosta Lima). In the 1990s, neoliberal narratives about "democratic transitions" in Latin America set the stage for deep and ongoing tensions between "autonomous" and "institutionalized" feminists-that is, between those who refuse to adopt 
organizational forms articulated with international development agencies, private foundations, and the market in general on the one hand, and those, on the other hand, who would compromise and adopt such forms in order to occupy spaces of political power for the sake of women's advancement in a liberal sense (see Lamas as well as Schild). In Schild's diagnosis, the problem with such an "institutionalization" of Latin American feminism was that instead of "creating collective spaces where women could articulate their own demands," it "tended to treat women as isolated individuals, with problems that can be solved through forms of differential clientelization" (71). Moreover, there are, inevitably, "winners" and "losers" of the institutionalization game: the winners are highly educated feminists who can demonstrate their specialist knowledge to foreign donors, and the losers are grassroots activists who start out at a disadvantage by lacking project-writing skills or credentials (71). After decades of such an internal conflict, Latin American feminisms are currently much more concerned with mass mobilization of women against the most recent and aggravated manifestations of structural violence, including sexual harassment and feminicides, neoliberal extractivism and environmental depletion than they are with developing academic, speculative, or even practical engagements with "science." The liberal record of second-wave feminism is being subjected in the process to a stern examination by the legatees of "autonomous" feminism. Some "autonomous" feminists eventually found an academic home in specific social science disciplines-especially those, like anthropology and rural sociology, which have a tradition of searching for dialogue with subaltern subjects (Hernández Castillo; Leyva Solana). Such a trajectory suggests that the sheer magnitude of historical inequalities between a minority of highly educated liberal feminists and the vast majorities of Latin American women might account for both the low priority of science and technology in the agendas of Latin American feminisms, and for the absence of a welldeveloped feminist critique of androcentric and Eurocentric understandings of "science and technology" within the agendas of Latin American STS. ${ }^{2}$

Even if STS and feminism evolved separately they both became institutionalized through power-knowledge compromises under neoliberal conditions, and in both cases such compromises have come under scrutiny in view of the aggravation of structural violence in the first decades of the twenty-first century, as recounted at the beginning of this section. Contemporary STS scholars in Latin America once again emphasize the persistence of imperial domination of Latin American societies through a globalized economy of

\footnotetext{
${ }^{2} 1$ thank my research assistant, Yareni Monteón López, for sharing this suggestion after conducting a search for recent Latin American research literature on the subject matter of this article. The overall conclusion of her search is that "science" has not been a priority or even a visible discussion topic in Latin American feminisms, although the epistemological and political critique of exclusion of indigenous and "other" knowledges has acquired prominence in recent "decolonial" discussions.
} 
knowledge and the need to recuperate the critical spirit of early Latin American thinkers on science and technology (De Greiff 365; Kreimer and Zukerfeld 178). However, rather than returning to militant essays demanding nationalist policy-making for science and technology, critical scholars in Latin American STS are currently searching for methodological innovations that bring back "the people" into research processes and that reconnect knowledge production with the region's social priorities (Vessuri 31-43). Feminist theoretical perspectives and gender analyses so far do not figure explicitly in STS. A potential site of articulation is given by the fact that neoliberal "democracy" is in question in Mexico as in the rest of Latin America, and I now turn to suggest that it would greatly benefit from calling into question the way in which the institutions of science and technology are implicated in structural violence, and specifically the role that a "gender perspective" is susceptible of playing within that implication.

\section{Gender and science in Mexico: A case of neoliberal feminism?}

A "gender perspective" in science policy was formalized in Mexican law in 2013 and can be summarized as the project of introducing equalityenhancement mechanisms that increase the presence and recognition of women in scientific research. Anticipating and accompanying the formalization of this "gender perspective," the Mexican Network of Science, Technology and Gender (Mexciteg) was launched in 2012 with the corresponding goal of fostering systematic exchange of experiences between organized women scientists across the Mexican republic, "as well as of developing a critical analysis of science and technology from a gender perspective that renders visible the participation, the promotion and the recognition of women within the national system of science and technology (Red Mexicana de Ciencia, Tecnología y Género). While one cannot underestimate the importance of promoting women's participation and recognition in all forms of knowledge production-a feminist effort that, in the case of Mexciteg, has already resulted in a wealth of knowledge about gender issues in the scientific education and the career prospects of Mexican women, all of it accessible through Mexciteg's open-access library-it seems equally important to articulate a feminist interrogation of the notions, practices, and narratives of "science" and "technology" that become institutionalized as well as destabilized through political struggles. As Sandra Harding asked almost three decades ago in "Women, Science, and Society," why should women want to find gender equality in sciences that have become so intimately involved with militarism, ecological disaster, social control, and capitalist exploitation and abandonment of the world's majorities? Taking heed of the well-known fact that women's interests and desires for knowledge are often "watered down or coopted" so that "the business of science and 
technology institutions comes with little change" (5), I propose to examine the ideological articulation of the "gender perspective" in Mexican science policy with the disturbing phenomenon of neoliberal feminism.

In a 2005 essay in Science and Society, Hester Eisenstein identified neoliberal feminism as a new and distinctively Eurocentric configuration of global feminism resulting from the massive entry of women to the workforce, the increasing attention of global corporations to women, and the political instrumentalization of feminist ideas by the war on terror. In a recent issue of the British cultural studies journal new formations, guest editors Sara Farris and Catherine Rottenberg take up Eisenstein's pioneering work to address the complex workings of neoliberal feminism across the Global North and South. A cultural and political phenomenon, neoliberal feminism mobilizes seductive individualist tropes such as work-life balance, professional success combined with maternity, happiness, and women's resilience. Half of the contributions to Righting Feminism analyze the ways in which high-power women, as the new face of global corporations, lead the conquest of new markets-that is, women in the so-called developing world-through publicprivate partnerships devoted to gender equality that take diverse shapes, from co-financing of projects to hybrid governance networks and networking platforms (Calkin 72). For instance, in 2016, Mexico was host to a Gender Summit, a global networking platform for gender experts, decision-makers in science policy, universities, and other "science stakeholders." With a neoliberal rhetoric that interlinks gender, individual careers in science, innovation, and "impact" through proprietary knowledge, the Gender Summit positions itself as a transnational influencer and trend-setter in Latin American public policies on gender and science. The Gender Summit that was hosted in Mexico was titled Science without Borders: Improving Impact by Interlinking Gender, Geographic, Disciplinary and Educational Dimensions. It included the participation of the National Council for Science and Technology (Conacyt) and several public universities, which suggests a straightforward link between the "gender and science" narrative in Mexican science policy and the neoliberal narratives of transnational business actors.

The origins of the Gender Summit lie in the genSET project funded between 2007 and 2012 by the European Commission, the goal of which was to improve the "excellence" of European science by means of genderbased knowledge. In its website, the Gender Summit clarifies that genSET had no definite position regarding the causes of gender inequality in science but recognizes that there are many different explanations and that regardless of that there is no reason to accept inequality, whereas evidence suggests that gender research can improve "scientific excellence." After 2012, genSET was continued by Portia Ltd, a British company led by information bioscientist and gender expert Elizabeth Pollitzer. Portia Ltd organizes the Gender 
Summit, which defines itself in its website as "quality research and innovation through equality" (Portia Ltd.). Like the original genSET, the Gender Summit starts with a recognition of "male bias" in scientific knowledge, one that it aims to correct through "dialog" among gender experts, scientists, science policy-makers, and other science stake-holders such as universities and corporations. Besides organizing the Gender Summit, Portia Ltd offers strategic consultancy to help individual men and women have the same opportunities to make a career in science through the promotion of collaborative work cultures, the assurance of quality in gender-sensitive science and, crucially, through showing how the development of new ideas and markets for scientific knowledge can include women as co-proprietors of knowledge. To achieve this goal Portia Ltd is partnered with the controversial data analytics corporation Elsevier (Buranyi). Elsevier is supposed to promote gender mainstreaming in scientific publishing, as well as to provide gender-sensitive metrics that help to measure the "impact" of gendersensitive science (Elsevier Foundation; Mobed). But is the privatization of knowledge through data analytics businesses really for the benefit of women and society? Is not gender rather being mobilized as a public relations strategy on the part of Portia Ltd and Elsevier, at the expense of a feminist critique of the knowledge economy? This would not be surprising in the light of other critiques of the business model of Elsevier and similar publishing and data analytic corporations. For instance, in the latest Radical Open Access Conference, Chris Kelty suggested that not only has knowledge been used as an instrument but also is now shaped as an instrument:

Are we not witnessing a transition to a world where scholarship is directed-in its very content and organization-towards the profitability of the "serve science"Elsevier's increasing acquisition of tools to control the entire life cycle of research, or ResarchGate's ambition to become the single source for all academics to network and share research-that these platforms might actually end up warping the very content of scholarly production in the service of their profitability?

Harding's feminist conviction was that the importance of "adding women" to the sciences was nothing less than a radical project, that of revealing and ultimately disrupting "the masculine subtext, or code, of Western institutions and the claims to knowledge that they produce" ("Women as Creators of Knowledge" 704). The Gender Summit's correction of male bias in science is figured as instrumental to the existing terms of a global knowledge economy, in which women are expected to become entrepreneurs and "co-proprietors" of knowledge understood as a commodity that must activate "new markets." Moreover, Portia promotes an articulation of this strategy with an understanding of science as innovation with "impact" on sustainable development. With such a vocabulary, regional platforms of the Gender Summit were created for Latin America, Africa, and the Arab World, where the 
Summit's stated mission is "to make science relevant to society." Such a colonization of Southern knowledge production through economic rearticulations of Eurocentric legacies that brand themselves by appealing to gender is certainly an issue for feminist science studies in Mexico and beyond. The contributors to Righting Feminism agree that gender has indeed acquired prominence on the global stage because it operates as a site for the generation of profit and as a legitimation of rising corporate power in the governance of global development. Eisenstein argues, moreover, that neoliberalism has not simply co-opted or instrumentalized feminism as Harding would have it but more radically, it has colonized thought and thereby given shape to a neoliberal kind of feminism that understands itself as the production of human capital under a cost-benefit logic. An incessantly calculative individual and entrepreneurial subjectivity has become the mark of contemporary feminism, fitting very well inside the hegemonic structures of knowledge production. Social justice, and justice more generally, are removed from the feminist agenda, which crucially entails an erasure of a critical tradition in feminist science studies. In Eisenstein's own words:

The ideas of "liberal" feminism-equal access for women at all levels of society, but most especially in the workforce-became synonymous with feminism tout court, and the radical edge of the movement, along with the contemporary program of groups like the Black Panthers, were silenced or brutally crushed. Above all the potential alliance of women in a broad anti-capitalist movement was no longer on the agenda. ("Hegemonic Feminism" 43).

In so far as the "gender perspective" in Mexican science policy does not question the neoliberal dynamics of global knowledge production, it renaturalizes Eurocentrism and effects a remasculinization of "science" by turning the ideal of "women in science" into a cog of capitalist subjectivation, by means of which competition and profit displace long-standing feminist concerns with social justice, cooperation, and care. These concerns appear to be better served by initiatives such as ANAA, which does not present itself as "feminist" and does not even foreground "women." Yet ANAA has constituted itself as a space for popular political education based on democratic practices of knowledge-making that respond to concrete experiences of structural violence. Through horizontal dialog between community leaders, concerned scientists, health professionals, law practitioners, and technological risk-assessment organizations, ANAA identified the connections between the socioenvironmental devastation wrought by free trade and the local health and insecurity crises that Mexico has seen multiply in recent years. ANAA's story suggests that socially concerned science starts with a practice of political articulation between unequally positioned knowledge producers and from there it works toward a diagnosis of the root causes of social problems and toward democratic solutions to those 
problems. In several workshops the people analyzed legal instruments and developed juridical skills, which helped them to protect themselves from state repression. In informative sessions organized by ETC Group-a 30year-old organization monitoring the impact of new technologies and lobbying against them at the UN-level-they discussed the profiteering drive of both governments and corporations in relation to climate change and were advised to anticipate the challenges posed by imminent convergence of dangerous technoscientific experiments such as geoengineering. Thus, ANAA members developed the material standpoint of the environmentally affected, which eventually crystallized in the Final Ruling of the Mexican Chapter of the Permanent Peoples' Tribunal (2009-2014). The PPT not only accused the Mexican state of structural violence against the Mexican people, as I mentioned earlier, but in doing so it legitimized the participation of the subjugated in knowledge construction, on a par with scientists and professionals of every sort. This is not to say that political conflicts inherent in the processes and outcomes of such a knowledge construction simply disappear, and the story of ANAA and the PPT reminds us instead of the most enduring insight of feminist standpoint epistemology, namely, that "standpoints are not to be conceptualized only as 'perspectives'; they are intellectual and political achievements, not ascriptions" (Harding, "Latin American Decolonial Feminisms" 413). What is then the feminist standpoint that could be articulated through a practice of FSS firmly situated in the Mexican context? Avenues to the articulation of such a standpoint have been opened by feminist anthropologists and other social scientists working closely with "autonomous" rural and indigenous women (Hernández Castillo, and Leyva Solana), a cultural and political critique of gender discourse in science policy, educational bureaucracies, and other sites of knowledge construction, such as I have initiated here in relation to the Gender Summit, may help to strengthen such efforts from within the interdisciplinary field of FSS. In the next section, I further argue that a feminist agenda needs to go beyond the liberal promotion of women in science toward a cultural, political, and ethical critique of the gendered dimensions of knowledge production under conditions of structural violence. The "feminism" of such a critique is there presented as having less to do with a representation of "women" than with an acknowledgment of the partiality of each of its singular efforts to account for the unequal experiences and the material complexity of structural violence. Therefore, rather than pre-defining Mexican FSS in a totalizing way, I end this article with an ethical commentary on a recent debate among a new generation of STS scholars, forensic anthropologists, and people searching for missing relatives. Through such a commentary I position a renewed, interdisciplinary practice of the Humanities as crucial to the development of a situated FSS in Mexico. 


\section{Futures of FSS: From disembodied "empowerment" to a material ethics of creative writing}

In a qualitative investigation of "the failure of Latin American intellectuals to claim a prominent place on the international academic stage," Enrique Mu and Milagros Pereyra-Rojas contend that such a failure cannot be attributed simply to the series of well-researched "lacks"-of knowledge, of peer-group support, of social stability, of fluency in English, of the appropriate rhetorical mode-of Latin American knowledge production. Drawing on a series of interviews, they argue that the marginality of Latin American voices in the international academic community is also due to how academics based in Latin America positively understand and practice their scholarship within their local and regional contexts. Whereas US/UK-based scholars see themselves mainly as experts in a research field that seeks to impact world-class knowledge, most of the Latin American scholars interviewed by $\mathrm{Mu}$ and Pereyra-Rojas identify themselves as social actors whose research is directly instrumental to the solution of pressing regional issues. The difference in priorities, which $\mathrm{Mu}$ and Pereyra-Rojas summarize as "impact on knowledge" versus "impact on society," can be partly illustrated through the contrast between the "gender perspective" in science policy embodied by the Gender Summit and the socially concerned science embodied by ANAA. From the perspective of knowledge geopolitics, perhaps the question about a future of FSS situated in Mexico appears to be, at least partly, a question about what kind of knowledge is FSS regarded to be by whom, what kind of impact it is expected to make on what and on whom, and what kind of feminism gets to critique, create, and intervene in Mexican cultural politics through FSS. What common ground might feminism and science studies articulate in response to Mexico's recent and devastating experience of structural violence under neoliberalism (1982-2018)?

As feminist sociologist Carolina Robledo observes, in Mexico what the search for missing persons foregrounds is the inequality in access to justice. Most often, the relatives of missing persons-who are often poor-resort to the discourse of human rights. Yet the discourse of human rights is an example of universalist knowledge that, as Robledo observes, tends to deactivate social protest by institutionalizing and bureaucratizing victimhood. In recent years citizen-led science has emerged as an alternative to institutionalization and bureaucratization of victimhood in the form of various initiatives of cooperation among forensic scientists and organized relatives. Such initiatives draw on a long tradition of socially concerned science in Latin America. As shown by STS scholars Smith and García Deister, Latin American forensic sciences have distinctively contributed to the notion of a socially concerned science, instrumental as they have been to processes of symbolic reparation and political democratization after military dictatorships. In Argentina, DNA 
identification techniques played a role through the identification of children abducted during the dictatorship. In Guatemala, forensic sciences helped to institutionalize notions of an expert-driven democracy aided by the United States, since the United States funded the equipment of Guatemalan forensic labs devoted to the identification of genocide victims. More recently, in Mexico, forensic sciences and genetic identification technologies have been at the center of civil society initiatives to support the search for the disappeared. The first independent team of forensic anthropologists of Mexico (EMAF), created in 2010, continues a lineage of socially concerned science that started with the aftermath of dictatorships in the Southern cone of Latin America. As did the pioneer Argentinian team of forensic anthropologists (EAAF), EMAF combines archaeological techniques with social research that includes nonjudgmental, strictly horizontal dialog with victims of structural violence.

The project known in Spanish as "Ciencia forense Ciudadana" (CfC) resulted from the initiative of two Mexican STS scholars based in the United Kingdom, Arely Cruz-Santiago and Ernesto Schwartz Marín. ${ }^{3}$ Since at least 2014, CfC has promoted the construction of an independent registry of forced disappearances and a biobank holding DNA samples provided by people who search for missing relatives. Calling to confront the monopoly of the state over dead bodies, CfC came to support relatives willing to "mobilize their own biology and that of their missing loved ones through DNA biobanks," and with an ethics of "co-production of knowledge" through "participatory biopolitics." Schwartz-Marín and Cruz-Santiago recount the disagreements that emerged between their project and some of its early collaborators. While forensic anthropologists became highly critical of an approach that promises technological achievement of truth and justice outside the rule of law (140), CfC presented itself as "a tool of civil disobedience," a radical practice of "techno-democracy," and a "feminist challenge to statism and authoritarianism" (149). The former argued that independent collection of biological evidence and independent use of genetic identification technologies would be of little use in establishing truth and in attaining justice, since truth and justice cannot be dissociated from the institutions of the law and its established protocols of forensic investigation. In response to this criticism, CfC elaborated a position statement that designates people who search independently as "associates in the development of research strategies and technologies, hand in hand with academics" (131). More precisely, however, CfC seeks the "empowerment" of citizens through their

\footnotetext{
${ }^{3}$ In 2014, Ernesto Schwartz-Marín and Arely Cruz-Santiago drew resources from the Economic and Social Research Council (ESCRC) for a project titled Citizen-Led Forensics: DNA and Databasing as Technologies of Disruption, Novel Ways to Learn and Intervene in the Search for the Disappeared. Besides ESCRC, CfC involves the participation of transnational actors as providers of DNA test tool-kits, digital infrastructure, and as external "custodians" of biological samples. See Schwartz-Marín and Cruz Santiago.
} 
transformation into "guardians, governors and managers of forensic technologies" (130). Here, I am interested in CfC's rhetoric of empowerment via scientific citizenship and, more specifically, I am interested in the claim that CfC is a feminist project because it achieves "empowerment" on a site of pain and vulnerability. Humanist narratives of "empowerment," I suspect, risk reproducing rather than displacing Eurocentric notions of "science" and "technology," and with them, the inequalities and injustices that characterize structural violence. Anne Huffschmid's alternative approach to citizen-led forensics suggests instead that ethical reflection on collaborative knowledgemaking under conditions of structural violence may be the core element of a feminist agenda for science studies in Mexico.

According to Stacy Alaimo and Susan Hekman, contemporary material feminisms "explore the interaction of culture, history, discourse, technology, biology, and the 'environment,' without privileging any of these elements" (7). In close spirit, Anne Huffschmid proposes to understand forensic science as "a situated science" not in the sense that it reflects the local standpoint of the subjugated, as if these were pre-constituted identities or owners of pain and vulnerability, or as if pain and vulnerability were sources of justice in an epistemological sense. Instead, Huffschmid invokes the materiality of bones as having themselves the capacity to interpellate humanity-that is, the institutions of justice-via the mediation of forensic anthropology as a situated science. In Huffschmid's narrative, forensic science emerges not as a universal technique but rather as a historically specific practice that operates, however, in a dimension that is neither that of relatives nor that of political activists. The historically specific practice of forensic sciences in Latin America operates instead in another dimension that has been denied, or silenced, by structural violence. This is a more than human, and even nonhuman dimension, the dimension of death, that can only attain social recognition by means of a labor of care, trust, and legitimacy earned by forensic science as a situated practice. Justice does not appear as the end result of humanist knowledge and control, but rather as a "cultural practice" - and I would say, a feminist ethics-which through the enactment of a historically specific sense of accountability, transgresses boundaries and breaks taboos surrounding death in order to allow for the social recognition of death within life. Huffschmid thus presents a very different reading of forensic science to the one mobilized by $\mathrm{CfC}$ as research partnerships for the "scientific empowerment" of citizens. Her reading shows how a situated science can depart from long-standing Western narratives of control, technical solutionism, and domination of life at the expense of death, without necessarily constituting itself as the representative of a particular human identity, including a particular feminist identity. While disembodied, masculine narratives of human agency or "empowerment" shape the ways in which notions of "science" and "technology" operate in activist imaginaries in 
contexts of structural violence, feminist ethics such as I find implicit in Huffschmid's reading of forensic science illuminate the dangers of "empowerment" rhetoric not just for women but for citizens more generally, as well as the researcher's obligation toward the delicate processes of legitimation and trust that concerned scientists and their victimized interlocutors are learning to cultivate in response to structural violence.

A situated praxis of FSS must critically address dominant narratives about "women in science" from the standpoint of social movements contesting the structural violence of neoliberalism. This does not mean that Western liberal commitments to "women in science" must be regarded as simply obsolete or irrelevant to the future of feminist science studies, but it does suggest that a Mexican iteration of feminist science studies must problematize their cultural, political, and philosophical limitations. In turn, the fact that feminism does not yet figure more explicitly or prominently in remarkable instances of scientific activism such as those reviewed here-the National Assembly of the Environmentally Affected and the public discussion of citizen-led forensic science-means that Mexican FSS studies has yet to define the ways in which it will enrich alternative or nonhegemonic engagements with science and technology. Drawing on my initial diagnosis of the separate trajectories of science studies and feminism, I suggest that a future for FSS in Mexico depends on critically working through historic political polarizations between privileged and underprivileged women, between "institutionalized" and "autononmous" feminists, between liberal or deessentializing intellectuals and grassroots, communitarian "womanists" (Lamas). Working through these polarizations, which are characteristic of Latin American feminisms (Garrigós), is not to downplay conflict-which I believe is ineradicable-but rather it is to try and create new spaces for feminist critique and creative experimentation across the disciplinary formations and the scholarly genres of Latin American discussions on knowledge production. After the demise of militant essays by men of science and technology, the tradition of academic activism in Latin America has belonged to the natural and the social sciences rather than to the Humanities. Today, Latin American STS scholars seem intent on recovering "impact on society" by means of "excellent" or positive science; that is, by means of a socially concerned science based on empirical case studies that involve the victims of structural violence as participants or "co-producers of knowledge." While positive science still has the aura of Eurocentric science-hence the rejection of that kind of science by contemporary critical anthropologists attempting to vindicate the subjugated knowledges of rural and indigenous people in Latin America (Leyva Solana) - one more potential contribution of a future FSS, Huffschmid's essay on "bones and humanity" suggests to me, lies in reinventing the philosophical and literary tradition of essay writing in Latin America, and to thereby position feminist critique, political debate, and 
ethical reflection on knowledge-making as a critical and creative articulator of militancy, scholarly production, and creative work (Zylinska). As a socially concerned Humanities scholar, I propose that the materiality of writing practices, and their potential to change the stories by which we live, is a nontotalizable site for the creation of a situated praxis of FSS in Mexico and beyond.

\section{Funding}

This work was supported by the Universidad Iberoamericana Ciudad de México, Dirección de Investigación [Investigación en Verano 2018].

\section{Works cited}

Alaimo, Stacy, and Susan Hekman. Material Feminisms. Indiana UP, 2008.

Álvarez, Sonia, and Beatriz da Costa Lima. “Turning to Feminisms." New Approaches to Latin American Studies. Culture and Power, edited by Juan Poblete, Routledge, 2017, pp. 161-78.

Álvarez-Buylla, Elena, and Alma Piñeyro Nelson. El Maíz en Peligro Ante Los Transgénicos. Un Análisis Integral Sobre El Caso de México. México, Universidad Nacional Autónoma de México, Unión de Científicos Comprometidos con la Sociedad, Universidad Veracruzana, 2013.

Asamblea Nacional de Afectados Ambientales. “¿Qué es la Asamblea Nacional de Afectados Ambientales.” Asamblea Nacional de Afectados Ambientales, Access 7 Mar. 2019, http://wp. afectadosambientales.org/?page_id=2

Blázquez Graf, Norma, and Javier Flores. Ciencia, Tecnología y Género en Iberoamérica. México, CEIICH-UNAM, Plaza y Valdés, 2005.

Brown, Wendy. Undoing the Demos: Neoliberalism's Stealth Revolution. MIT Press, 2017.

Buranyi, Stephen. "Is the Staggeringly Profitable Business of Scientific Publishing Bad for Science?”, The Guardian, 27 Jun. 2017, https://www.theguardian.com/science/2017/jun/27/ profitable-business-scientific-publishing-bad-for-science.

Calkin, Sydney. "Disrupting Disempowerment: Feminism, Co-Optation, and the Privatised Governance of Gender and Development." New Formations, vol. 91, 2017, pp. 69-86. doi:10.3898/NEWF:91.04.2017.

Casas Guerrero, Rosalba. "Conocimiento, Tecnología y Desarrollo en América Latina." Revista Mexicana de Sociología, vol. 66, no. special issue, 2004, pp. 255-77. doi:10.2307/ 3541453.

Castillo, Hernández. Multiple Injustices: Indigenous Women, Law, and Political Struggle in Latin America. U of Arizona P, 2016.

Castillo, Hernández, and Rosalva Aída. "Hacia una antropología socialmente comprometida desde una perspectiva dialógica y feminista." Prácticas otras de conocimiento(s): Entre crisis, entre guerras. Tomo II, edited by Xóchitl Leyva Solana, Cooperativa Editorial RETOS, Taller Editorial La Casa del Mago, CLACSO, 2015, pp. 83-106.

Cipolla, Cyd, et al. Queer Feminist Science Studies: A Reader. U of Washington P, 2017.

De Greiff, Alexis. "La Norteamericanización de La Tecnociencia en América Latina: Diplomacia Científica y Hegemonía Cultural.” Perspectivas Latinoamericanas en El Estudio Social de La Ciencia, La Tecnología y La Sociedad, edited by Pablo Kreimer, et al., Foro Consultivo Científico y Tecnológico y Siglo XXI Editores, 2014, pp. 365. 
Eisenstein, Hester. "A Dangerous Liaison? Feminism and Corporate Globalization.” Science and Society, vol. 69, no. 3, 2005, pp. 487-518. doi:10.1521/siso.69.3.487.66520.

Eisenstein, Hester. "Hegemonic Feminism, Neoliberalism and Womenomics." New Formations, vol. 91, 2017, pp. 35-49. doi:10.3898/NEWF:91.02.2017.

Elsevier Foundation. "Diversity in STM." The Elsevier Foundation, Access 6 Mar. 2019, https://www.elsevierfoundation.org/programs/diversity-in-stm/

Espinoza, Raymundo. "El desvío de poder legislativo." La Audiencia Final (12 al 15 de noviembre de 2014) Sentencia, Fiscalía y Relatorías. Capítulo México del Tribunal Permanente de los Pueblos (2011-2014), edited by Andrés Barreda, Editorial Ítaca, 2016, pp. 210.

Farris, Sara, and Catherine Rottenberg. "Introduction to Righting Feminism." New Formations, vol. 91, 2017, pp. 1-11. doi:10.3898/NEWF:91.INTRODUCTION.2017.

Finnemore, Martha. "International Organizations as Teachers of Norms: The United Nations Educational, Scientific, and Cultural Organization and Science Policy." International Organization, vol. 47, no. 4, 1993, pp. 565-97. doi:10.1017/S0020818300028101.

Flores Espíndola, Artemisa. "¿Los estudios CTS tienen un sexo? Mujeres y género en la investigación académica." Revista Iberoamericana de Ciencia, Tecnología y Sociedad, vol. 11, no. 31, 2016, pp. 61-92.

Garrigós González, Cristina. "Feminismos." Conceptos Fundamentales del Pensamiento Latinoamericano Actual, edited by Alberto Moreiras, et al., Kindle Edition, 2017.

Gender Summit. "Background." Portia Ltd, Access 6 Mar. 2019, https://gender-summit.com/ gs-background.

Haraway, Donna. "Situated Knowledges: The Science Question in Feminism and the Privilege of Partial Perspective." Feminist Studies, vol. 14, no. 3, 1988, pp. 575-99. doi:10.2307/ 3178066.

Haraway, Donna. Modest _ Witness @ Second _ Millennium.FemaleMan@ _ Meets _ OncoMouseTM: Feminism and Technoscience. Routledge, 1997.

Harding, Sandra. "Women as Creators of Knowledge." American Behavioral Scientist, vol. 32, no. 6, 1989, pp. 700-07. doi:10.1177/0002764289032006009.

Harding, Sandra. "Women, Science, and Society." Science, vol. 281, no. 5383, 1998a, pp. 1599-600. doi:10.1126/science.281.5383.1599.

Harding, Sandra. Is Science Multicultural? Postcolonialisms, Feminisms, and Epistemologies. Indiana UP, 1998b.

Harding, Sandra. "Postcolonial and Feminist Philosophies of Science and Technology: Convergences and Dissonances." Postcolonial Studies, vol. 12, no. 4, 2009, pp. 401-21. doi:10.1080/13688790903350658.

Harding, Sandra. "Latin American Decolonial Social Studies of Scientific Knowledge: Alliances and Tensions." Science, Technology, \& Human Values, vol. 41, no. 6, 2016, pp. 1063-87. doi:10.1177/0162243916656465.

Harding, Sandra. "Latin American Decolonial Studies: Feminist Issues." Feminist Studies, vol. 43, no. 3, 2017, pp. 624-36. doi:10.15767/feministstudies.43.3.0624.

Hernández Castillo, Rosalva Aída. Multiple Injustices: Indigenous Women, Law, and Political Struggle in Latin America. U of Arizona P, 2016.

Huffschmid, Anne. "Huesos y Humanidad. Antropología Forense y Su Poder Constituyente ante La Desaparición Forzada." Athenea Digital, vol. 15, no. 3, 2015, pp. 195-214. doi:10.5565/rev/athenea.1565.

Joseph, Gilbert, et al. editors. Fragments of a Golden Age: The Politics of Culture in Mexico since 1940. Duke UP, 2001.

Kelty, Chris. "Recursive Publics and Open Access." Paper presented at the Radical Open Access Conference II, "The Ethics of Care". Coventry University, 2018. 
Kreimer, Pablo, et al. editors. Perspectivas Latinoamericanas en El Estudio Social de La Ciencia, La Tecnología y La Sociedad. Foro Consultivo Científico y Tecnológico and Siglo XXI Editores, 2014.

Kreimer, Pablo, and Mariano Zukerfeld. "La explotación cognitiva.” Perspectivas latinoamericanas en el estudio social de la ciencia, la tecnología y la sociedad, edited by Pablo Kreimer, et al., Foro Consultivo Científico y Tecnológico y Siglo XXI Editores, 2014, pp. 178.

Lamas, Marta. Feminism. Transmissions and Retransmissions. US Palgrave, 2011.

Leyva Solano, Xóchitl editor. Prácticas otras de conocimiento(s): Entre crisis, entre guerras. Tomo I. Cooperativa Editorial RETOS, Taller Editorial La Casa del Mago, CLACSO, 2015a.

Leyva Solano, Xóchitl ed. Prácticas otras de conocimiento(s): Entre crisis, entre guerras. Tomo II. Cooperativa Editorial RETOS, Taller Editorial La Casa del Mago, CLACSO, 2015b.

Lopes, Maria, et al. "Intersecções: Gênero en Ciências e Tecnologias en América Latina." Perspectivas latinoamericanas en el estudio social de la ciencia, la tecnología y la sociedad, Foro Consultivo Científico y Tecnológico y Siglo XXI Editores, 2014, pp. 233-43.

Lugones, Maria. "The Coloniality of Gender." Globalization and the Decolonial Option, edited by Walter Mignolo and Arturo Escobar, Routledge, 2010, pp. 369-90.

Lyons, Kristina, et al. "Engagements with Decolonization and Decoloniality in and at the Interfaces of STS.” Catalyst: Feminism, Theory, Technoscience, vol. 3, no. 1, 2017, pp. 1-47. doi:10.28968/cftt.v3i1.

Medina, Eden, et al. editors. Beyond Imported Magic: Essays on Science, Technology, and Society in Latin America. MIT Press, 2014.

Mendoza, Breny. "Coloniality of Gender and Power: From Postcoloniality to Decoloniality." The Oxford Handbook of Feminist Theory, edited by Lisa Disch and Mary Hawkesworth, Oxford UP, 2015, pp. 100-21.

Mobed, Ron. "How Gender Summits Have Shaped Elsevier's Role in the Research Community." Elsevier, 20 Jun 2018, https://www.elsevier.com/connect/how-gendersummits-have-shaped-elseviers-role-in-the-research-community.

$\mathrm{Mu}$, Enrique, and Milagros Pereyra-Rojas. "Impact on Society versus Impact on Knowledge. Why Latin American Scholars Do Not Participate in Latin American Studies." Latin American Research Review, vol. 50, no. 2, 2015, pp. 216-38. doi:10.1353/lar.2015.0021.

O’Toole, Gavin. The Reinvention of Mexico. National Ideology in a Neoliberal Era. Liverpool UP, 2014.

Pérez-Bustos, Tania. "A Word of Caution toward Homogenous Appropriations of Decolonial Thinking.” Catalyst: Feminism, Theory, Technoscience, vol. 3, no. 1, 2017, pp. 39-47.

Permanent Peoples' Tribunal. "Free Trade, Violence, Impunity and Peoples' Rights in Mexico (2011), Final Hearing Ruling." 12-15 Nov. 2014, http://permanentpeoplestribunal.org/wpcontent/uploads/2012/07/SENTENCIAFINAL_MEXICOingles.doc.pdf.

Pollock, Anne, and Banu Subramaniam. "Resisting Power, Retooling Justice: Promises of Feminist Postcolonial Technosciences.” Science, Technology \& Human Values, vol. 41, no. 6, 2016, pp. 951-66. doi:10.1177/0162243916657879.

Portia Ltd. “About Us.” Portia Ltd. Access 6 Mar. 2019, https://portiaweb.org.uk/about.html. Red Mexicana de Ciencia, Tecnología y Género. "Quiénes somos.” Red Mexicana de Ciencia, Tecnología y Género. Access 31 Dec. 2018, http://redmexciteg.org/sobre-la-red/quienessomos

Robledo, Carolina. "El laberinto de las sombras: Desaparecer en el marco de la Guerra contra las drogas." Estudios políticos, vol. 47, 2015, pp. 89-108.

Rose, Hilary. Love, Power and Knowledge. Towards a Feminist Transformation of the Sciences. Cambridge and Malden, Polity Press, 1994.

Rose, Hilary, and Steven Rose. The Radicalisation of Science. Ideology Of/In the Natural Sciences. The MacMillan Press, 1976. 
Runyan, Anne S., and V. Spike. Peterson. Global Gender Issues in the New Millennium. Westview Press, 2014.

Schild, Verónica. "Feminism and Neoliberalism in Latin America." New Left Review, 96, Nov.-Dec 2015, pp. 59-74.

Schmidt, Arthur. "Making It Real Compared to What? Reconceptualizing Mexican History since 1940." Fragments of a Golden Age: The Politics of Culture in Mexico since 1940, edited by Gilbert Joseph, et al., Duke UP, 2001, pp. 23-70.

Schoijet, Mauricio, and Richard Worthington. "Globalization of Science and Repression of Scientists in Mexico." Science, Technology, and Human Values, 1993, pp. 209-30. doi10.1177/016224399301800206.

Schwartz-Marin, Ernesto, and Arely Cruz-Santiago. "Antígona y su biobanco de ADN: Desaparecidos, búsqueda y tecnologías forenses en México.” Athenea Digital, vol. 18, no. 1, 2017, pp. 129-53.

Smith, Lindsay A., and Vivette García-Deister. "Capturing Los Migrantes Desaparecidos: Crisis, Unknowability, and the Making of the Missing." Perspectives on Science, vol. 25, no. 5, Sept 2017, pp. 680-97. doi: 10.1162/POSC_a_00259.

Smith, Lindsay A., and Vivette García-Deister. "Ensamblajes de la ciencia forense en América Latina." Aproximaciones a Lo Local Y Lo Global: América Latina, edited by Edna Suárez Díaz and Gisela Mateos, Centro de estudios filosóficos, políticos y sociales Vicente Lombardo Toledano, 2016, pp. 270-300.

Wiley, Angela. "A World of Materialisms: Postcolonial Feminist Science Studies and the New Natural.” Science, Technology \& Human Values, vol. 41, no. 6, 2016, pp. 991-1014. doi:10.1177/0162243916658707.

Zylinska, Joanna. Minimal Ethics for the Anthropocene. Open Humanities Press, 2014. 